JURNAL TERKNOSAINS

VOLUME 3

No. 1, 22 Desember 2013

Halaman 1-80

\title{
MODEL INTEGRASI DESIGN DAN PROSES MANUFAKTUR PADA PERAKITAN PRODUK MULTI-PEMASOK
}

\author{
Budi Susanto, MK Herliansyah, dan Alva Edy Tontowi \\ Jurusan Teknik Industri Fakultas Teknik Universitas Gadjah Mada \\ Email: Susantobudi1810@ymail.com
}

\begin{abstract}
In Product design process, aspects related to the manufacturing process and supply chain should be considered. The design is produced not only satisfy for consumers needs but it fulfilled the constraints related to manufacturing and supply chain aspects. This research aims to make a model to determine the cheapest product design from both of manufacturing process and supply chain. This research uses binary programming as an approach. The cost aspects used in this research are component's manufacturing cost, supplier fixed contact cost, assembly operation cost and quality improvement cost. The result of research, a physical product design with the lowest total cost by combining components from several designs and adding the value constraint on the quality specification.
\end{abstract}

Keywords: Process Selection, Supplier Fixed Contact Cost and Quality Improvement Cost.

\begin{abstract}
ABSTRAK
Pada proses perancangan produk, aspek-aspek yang terkait dengan proses manufaktur dan rantai pasok harus dipertimbangkan. Rancangan yang dihasilkan bukanhanya dapat memenuhi kebutuhan konsumen namun juga memenuhi batasan-batasan yang terkait dengan aspek manufaktur dan rantai pasok. Model pemilihan rancangan produk pada penelitian ini bertujuan untuk memilih satu rancangan komponen pada setiap set alternatif rancangan yang dimiliki oleh tiap-tiap komponen sehingga menghasilkan sebuah rancangan produk yang biaya manufakturnya paling murah. Metode pemecahan masalah yang digunakan pada penelitianini adalah binary integer linear programming. Model dapat bekerja untuk memilih komponen dengan kriteria performansi biaya manufaktur/pembelian, biaya pelibatan pemasok/subkontraktor, biaya perakitan, dan biaya kerugian kualitas. Solusi yang dihasilkan model berupa sebuah rancangan produk dengan kombinasi rancangan komponen dan kombinasi pemasok/subkontraktor yang memberikan biaya total terendah.
\end{abstract}

Kata Kunci: Pemilihan Rancangan Produk, Biaya Pelibatan Pemasok, Biaya Kualitas 


\section{PENGANTAR}

Concurrent engineering (CE) atau Rekayasa Simultan merupakan suatu pendekatan sistematis yang diterapkan pada proses perancangan produk dengan cara mengintegrasikan berbagai aspek yang berperan dalam siklus hidup produk seperti aspek manufaktur, rantai pasok, kualitas. Pendekatan CE juga mempertimbangkan pada proses eliminasi terhadap kegiatankegiatan yang bersifat non-added value. Concurrent engineering (CE) adalah sebuah gagasan yang ditujukan untuk menutup kelemahan pada konsep serial dari proses perancangan (Gunasekaran,1998). Konsep CE memungkinkan keputusan yang berkaitan dengan perancangan produk dan proses produksisedapatmungkindibuatsecaraparalel dan pertimbangan-pertimbangan produksi dapat diakomodasikan ke dalam tahapan awal pada proses desain (Fine,et.al. 2005). Penerapan dari konsep CE dilaporkan mampu menurunkan 30-60\% waktu untuk penetrasi pasar, $15-50 \%$ biaya siklus hidup produk dan 55-95\% permintaan untuk perubahan teknis (Bopana dan Chon Huat, 1997). Penelitian awal yang terkait dengan konsep 3D-CE dilakukan oleh Feng,et al. (2001).

Menurut Feng,et.al (2001) dalam penelitiannya bahwa mengembangkan sebuah model untuk menentukan toleransi dari dimensi-dimensi yang terdapat pada rancangan produk dengan multi komponen. Tidak hanya itu, pada model Feng,et.al (2001) juga mampu menentukan subkontraktor yang akan dilibatkan dalam pembuatan produk berdasarkan biaya manufaktur dan biaya kerugian kualitas. Akan tetapi, model Feng,et al.(2001) belum mampu memilih rancangan komponen yang memberikan biaya termurah.

Sedangkan Fine, et.al (2005) dalam penelitiannya membangun sebuah model untuk pemilihan rancangan produk. Pada penelitian yang telah dilakukan oleh Fine,et. al(2005) diusulkan sebuah pendekatan untuk mengevaluasi berbagai tradeoff yang terjadi pada proses pengembangan produk.Model yang dikembangkan penelitian ini bertujuan untuk memilih sebuah konfigurasi yang terdiri atas rancangan produk, urutan proses perakitan dan rancangan sistem rantai pasok dari sejumlah alternatif konfigurasi yang tersedia. Model yang dihasilkan Fine, et.al (2005) belum dapat menghasilkan sebuah konsep rancangan fisik produk baru melainkan hanya memilih dari sejumlah alternatif rancangan yang tersedia dan belum memperhitungkan penentuan nilai toleransi kualitas rancangan produk. Oleh karena itu, perlu dilakukan penelitian yang menjembatani gap antara penelitian perancangan proses (design process) dengan penelitian perbaikan kualitas yang menghasilkan model pemilihan komponen produk sehingga dihasilkan sebuah rancangan produk baru yang biaya manufakturnya murah juga mempertimbangkan faktor kontinuitas pasokan komponen dengan cara memberikan nilai bobot pada biaya manufaktur komponen (Rizkianda, 2009).

\section{Pengembangan Model Model Konseptual}

Model umum pada penelitian ini adalah model biaya produksi. Parameter biaya yang digunakan pada penelitian ini adalah biaya manufaktur (Rizkianda, 2009), biaya pelibatan pemasok (Fine, et.al 2005), biaya perakitan komponen dan biaya kualitas (Irianto dan Rachmat, 2008). Susunan struktur rancangan produk dibuat berdasarkan bentuk arsitektur produk. Pada langkah ini dilakukan proses identifikasi komponenkomponen dasar produk dan dibuatkan skema yang menjelaskan hubungan keterkaitan antar komponen. Skema hubungan keterkaitan antar-komponen merupakan representasi proses perakitan. Representasi proses perakitan berisi informasi karakteristik dari sebuah rencana perakitan. Akan tetapi, sebelum karakteristik rencana perakitan dianalisis, maka informasi produk dikumpulkan terlebih dahulu. Informasi produk dapat disajikan dalam bentuk grafik 
yang berisi penjelasan tingkatan sebuah produk dari yang paling rendah, yaitu komponen sampai tingkat tertinggi produk akhir. Contoh informasi komponen dan subrakitan dari sebuah produk diperlihatkan pada Gambar 1.

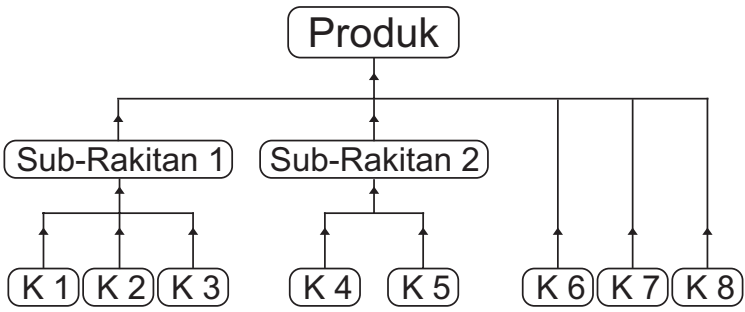

Gambar 1. InformasiKomponendan subrakitansebuahproduk

Pada sistem perakitan, input tidak hanya berupa komponen atau sub-rakitan, tetapidapat berupa gabungan keduanya (Marian, 2003). Setelah informasi produk telah disusun, maka karakteristik rencana perakitan diidentifikasi untuk menghasilkan representasi perakitan. Representasi perakitan terdiri dari penentuan karakteristik rencana perakitan, pencarian informasi mengenai gambaran komponen, dan operasi perakitannya (Informasi mengenai hubungan keutamaan antar-komponen). Keluaran dari tahap representasi perakitan ini merupakan input untuk tahap selanjutnya (tahap penentuan urutan perakitan) dari perencanaan perakitan.

Liason graph berisi informasi hubungan keterkaitan antar-komponen yang disajikan dalam bentuk grafik. Garis yang menghubungkan dua komponen menunjukan bahwa kedua part tersebut berhubungan. Incidence Matrix memberikan informasi yang sama dengan Liason graph, tetapi disajikan dalam bentuk matrik. Angka 1 menunjukan adanya hubungan antar-komponen sedangkan angka 0 menunjukan tidak ada hubungan antar-komponen. Sedangkan Assembly Precedence Diagram (APD) adalah skema yang digunakan untuk menunjukan hubungan keutamaan antar-proses perakitan.
Urutan proses merakit produk yang diperoleh dari pengambaran skema produk dijadikan input untuk perhitungan pada model. Penentuan urutan perakitan dibuat berdasarkan hubungan keterkaitan dan hubungan keutamaan antar-komponen dalam produk bukan berdasarkan urutan perakitan yang memberikan nilai biaya termurah atau waktu terpendek. Dengan demikian, ilustrasi struktur rancangan produk contoh pada Gambar 2.
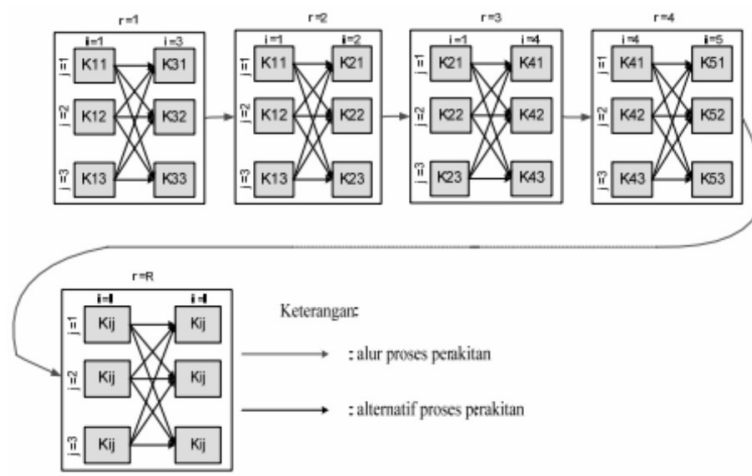

Gambar 2.Ilustrasi struktur rancangan produk contoh

Ilustrasi struktur rancangan produk contoh pada Gambar 2, dapat terlihat beberapa alternatif rancangan produk yang dapat dihasilkan. Gambar 2 menunjukan bahwa produk contoh memiliki proses rakitan sejumlah $R$, pada setiap proses perakitan $r$ terdapat alternatif proses $u$ sejumlah U. Jumlah komponen pada produk dinyatakan dengan indeks I sedangankan jumlah alternatif rancangan komponen produk dinyatakan dengan indeks J.

$$
\begin{aligned}
& \text { Indeks } \\
& \text { i } \quad \text { :komponen, } \mathrm{i}=(1,2, \ldots, \mathrm{I}) \\
& \mathrm{j} \quad \text { :alternatif rancangan, } \mathrm{j}=(1,2, \ldots, \mathrm{J}) \\
& \mathrm{s} \quad \text { :pemasok/pabrik manufaktur, } \mathrm{s}=(0 \text {, } \\
& 1,2, \ldots, \mathrm{S}) \\
& \text { r :proses/kegiatan perakitankomponen, } \\
& r=(1,2,3, \ldots, R) \\
& \mathrm{u} \text { :alternatif proses/kegiatan perakitan } \\
& \text { komponen, } \mathrm{u}=(1,2,3, \ldots, \mathrm{U})
\end{aligned}
$$




\section{Parameter}

$\mathrm{bp}_{i j s} \quad$ : biaya produksi komponen $i$ rancangan ke- $j$ yang ditanggung pemasok/ pabrik manufaktur $s$.

$\mathrm{P}_{\text {is }} \quad$ : biaya yang berkaitan dengan upaya pelibatan pemasok/pabrikmanufaktur $s$ dalam pengadaan komponen $i$ (Fine, et.al 2005).

$\mathrm{P}_{i j s}\left(\mathrm{t}_{0}\right)$ : biaya manufaktur/harga komponen $i$ rancangan ke-j pada pemasok/pabrik manufaktur $s$ pada saat $t_{0}$.

$\mathrm{P}_{i j s}(\mathrm{t})$ : biaya manufaktur/harga komponen $i$ rancangan ke-j pada pemasok/pabrik manufaktur s pada saat sekarang.

$\mathrm{P}_{r i u}$ : biaya proses perakitan $r$ rancangan komponen ke-j pada alternatif proses $u$.

$\mathrm{Tk}_{i j s}$ :prediksi lama kontinuitas pasokan komponen $i$ rancangan ke- $j$ dari pemasok $s$

Tp : rencana masa produksi yang ditetapkan oleh perusahaan

$\mathrm{Wp}_{i j s}$ : biaya berbobot untuk proses manufaktur/pembelian komponen $i$ rancangan ke-j pada pemasok/pabrik manufaktur s. (Rizkianda, 2009)

$\mathrm{QL}_{i j s}$ : biaya kualitas (Irianto dan Rahmat, 2009)

Variabel

$\mathrm{x}_{i j \mathrm{~s}} \quad$ : variabel biner yang mewakili komponen $i$ rancangan ke-j dari pemasok/pabrik manufaktur $s$.

$\mathrm{y}_{\text {is }} \quad$ : variabel biner yang mewakili keterlibatan pemasok/pabrik manufaktur $s$ dalam pengadaan komponen $i$.

$\mathrm{a}_{r j u} \quad$ :variabel biner yang mewakili proses perakitan $r$ rancangan komponen ke- $j$ dengan pilihan alternatif ke- $u$.

\section{Model Dasar dan Fungsi Tujuan}

Fungsi tujuan dari model adalah minimasi biaya produksi total yaitu biaya manufaktur, biaya pelibatan pemasok, biaya perakitan, dan biaya kualitas.

Biaya manufaktur/pembelian komponen $M\left(x_{i j}\right)$ merupakan biaya yang diperlukan untuk membuat/membeli komponen dari pemasok atau pabrik manufaktur. Jadi dalam biaya ini sudah termasuk biaya transportasi dari pemasok/pabrik manufaktur ke perusahaan, biaya material serta biaya produksi, dan keuntungan pemasok/pabrik manufaktur.

$\mathrm{M}\left(x_{i j s}\right)=\sum_{i=1}^{I} \sum_{j=1}^{J} \sum_{s=0}^{S} w_{p i j s} x_{i j s}$

Dari Persamaaan (1), terlihat bahwa biaya manufaktur/pembelian komponen merupakan perkalian antara biaya berbobot manufaktur/pembelian komponen $i$ rancangan ke-j pada pabrik manufaktur/ pemasok $s$ dengan variabel biner yang mewakilinya. Untuk mempertimbangkan aspek kontinuitas pasokan khususnya untuk komponen-komponen yang dibeli dari pemasok (bukan dibuat in-house atau dipesan khusus kepada subkontraktor) maka dalam menentukan nilai $W p_{i j s}$ diberikan nilai bobot yang mencerminkan aspek kontinuitas (Rizkianda, 2009). Nilai bobot yang diberikan merupakan perbandingan antara rencana masa produksi (Tp) dengan prediksi sisa waktu sebelum komponen $i$ rancangan ke- $j$ dihentikan produksinya oleh pemasok/ pabrik manufaktur $s\left(T k_{i j s}\right)$. Sehingga nilai $p_{i j s}$ dihasilkan melalui Persamaan (2):

$w_{p i j s}=\left\{\begin{array}{c}\left(\frac{T p}{T k_{i j s}}\right) p_{i j s}(t) ; T p>T k_{i j s} \\ p_{i j s}(t) ; T p \leq T k_{i j s}\end{array}\right.$

Biaya pelibatan pemasok/pabrik manufaktur sub-kontraktor $F($ yis) adalah biaya yang dikeluarkan untuk melibatkan pemasok/pabrik manufaktur subkontraktor $s$ ke dalam sistem manufaktur. Model pada penelitian ini biaya pelibatan pemasok/ pabrik manufaktur subkontraktor dibedakan berdasarkan komponen sehingga dinotasikan sebagai Pis. Sehingga nilai F(yis) dapat ditulis seperti dalam Persamaan (3):

$\mathrm{F}\left(y_{i s}\right)=\sum_{i=1}^{I} \sum_{s=0}^{S} p_{i s} y_{i s}$

Dari persamaaan (3), dapat diketahui bahwa nilai $F(y i s)$ merupakan perkalian dari biaya pelibatan pemasok/sub-kontraktor $s$ untuk pengadaan komponen $i$ dengan 
variabel biner yang mewakilinya. Variabel biner tersebut mewakili terpilihnya biaya pelibatan pemasok/sub-kontraktor $s$ dalam pengadaan komponen $i$ seiring terpilihnya pemasok/sub-kontraktor $s$ pada pemilihan rancangan komponen.

Biaya perakitan komponen merupakan biaya langsung (direct cost) yang ditanggung perusahan untuk merakit komponen menjadi produk jadi. Model ini biaya perakitan dinotasikan sebagai $R\left(a_{r j u}\right)$.

$\mathrm{R}\left(a_{r j u}\right)=\sum_{r=1}^{R} \sum_{j=0}^{J} \sum_{u=0}^{u} p_{r j u} a_{r j u}$

Dari Persamaan (4), diketahui bahwa biaya perakitan produk merupakan jumlah biaya proses perakitan komponen. Variabel $a_{r i u}$ merupakan variabel keputusan yang mewakili proses perakitan $r$ rancangan ke- $j$ alternatif ke- $u$. Indeks $r$ mewakili urutan proses perakitan dan indeks $u$ mewakili alternatif proses pada tiap tahapan perakitan.

Ongkos kerugian kualitas yang dipilih adalah ongkos yang paling minimum di antara alternatif yang ada pada setiap komponen ke- $i$ dari setiap alternatif proses ke-j pada pemasok ke-s. Pemilihan dilakukan dengan memasukkan variabel keputusan $x_{i j s}$ pada fungsi ongkos kerugian kualitas pada Persamaan (5):

$Q L_{i j s}=A_{P}\left(\sum_{i=1}^{I} \sum_{j=1}^{I} \sum_{s=0}^{s} \ldots\left(\left.\frac{\partial y}{\partial x_{1}}\right|_{\kappa=1}\right)^{2}\left(\frac{\mathbf{t}_{\mathrm{ijs}}}{3}\right)^{2}\right) \cdot x_{i j s}$

Sehingga rumusan fungsi tujuan dapat diringkas sebagai berikut:

$\operatorname{Min} T C=\sum_{i=1}^{I} \sum_{i=1}^{I} \sum_{s=0}^{S} w_{p i j s} x_{i j s}+\sum_{i=1}^{I} \sum_{s=0}^{S} p_{i s} y_{i s}$

$$
+\sum_{r=1}^{R} \sum_{j=0}^{I} \sum_{u=0}^{U} p_{r j u} a_{r j u}+A_{P}\left(\sum_{i=1}^{I} \sum_{j=1}^{I} \sum_{s=0}^{S} \cdots\left(\left.\frac{\partial y}{\partial x_{1}}\right|_{\pi \times 1}\right)^{2}\left(\frac{\mathbf{t}_{i j}}{3}\right)^{2}\right) \cdot x_{i j s}
$$

\section{Kendala}

Untuk lebih memfokuskan penelitian ini, maka diambil sejumlah batasan masalah sebagai berikut: pertama, Penelitian dilakukan dalam lingkup perancangan proses (process design), yaitu menentukan proses manufaktur yang dapat membuat produk dalam batasbatas toleransi yang ditentukan pada ongkos yang minimum. Kedua, Parameter yang digunakan penelitian ini adalah biaya manufaktur komponen, biaya pelibatan pemasok/subkontraktor, biaya operasi perakitan komponen, biaya kualitas. Ketiga, Toleransi yang diperhitungkan adalah toleransi dimensi yang bersifat bilateral, yaitu besarnya toleransi pada dua sisi bernilai sama. Keempat, Sifat karakteristik kualitas adalah nominal is the best, yaitu nilai target karaktersitik kualitas yang terbaik tepat berada di tengah dan nilai sesungguhnya berkurang ke arah dua sisi secara kuadratik.

Fungsi pembatas yang digunakan pada model ini antara lain:

1. Fungsi pembatas untuk memastikan hanya ada satu rancangan komponen yang terpilih:

$$
\sum_{j=1}^{J} \sum_{s=1}^{S} x_{i j s}=0, \quad \forall i, x_{i j s}=\{0\}
$$

2. Fungsi pembatas untuk memastikan bahwa tiap-tiap komponen dipasok oleh satu pemasok/pabrik manufaktur sub-kontraktor:

$$
\sum_{s=0}^{S} y_{i s}=1, \quad \forall i, y_{i s}=\{0,1\}
$$

3. Fungsi pembatas untuk memastikan bahwa hanya satu alternatif proses yang terpilih pada tiap-tiap tahapan proses perakitan:

$\sum_{u=1}^{u} a_{r j u}=1, \quad \forall r, \forall j, a_{r j u}=\{0,1\}$

4. Fungsi pembatas untuk memastikan bahwa hanya ada satu pemasok/pabrik manufaktur/sub-kontraktor yang akan memasokt iap-tiap rancangan komponen: $\sum_{s=0}^{S} x_{i j s}-\sum_{s=0}^{S} y_{i s}=0, \forall i, \forall j, x_{i j s}$ $=\{0,1\}, y_{\text {is }}=\{0,1\}$

5. Fungsi pembatas untuk memastikan proses logika urutan perakitan sesuai dengan alternatif proses yang dipilih:

$\sum_{r=2}^{R} \sum_{u=1}^{U} a_{r j u}-\sum_{r=1}^{R-1} \sum_{j=1}^{J} a_{r j u}=0, a_{r j u}=\{0,1\} \forall u, \forall j$

6. Fungsi pembatas untuk memastikan proses perakitan akan merakit komponen yang terpilih: 


$$
\begin{aligned}
& \sum_{i=1}^{I} \sum_{j=1}^{I} \sum_{s=0}^{S} x_{i j s}-\sum_{r=1}^{R} \sum_{j=1}^{I} \sum_{u=1}^{U} a_{r j u}=0, x_{i j s}=\{0,1\} a_{r j u} \\
& \sum_{i=2}^{I} \sum_{j=1}^{I} \sum_{s=0}^{S} x_{i j s}-\sum_{r=1}^{R} \sum_{j=1}^{I} \sum_{u=1}^{U} a_{r j u}=0, x_{i j s}=\{0,1\} a_{r j u}
\end{aligned}
$$

7. Pembatas spesifikasi kualitas

Nilai toleransi kualitas produk akhir dari skenario rancangan proses, dengan memperhatikan $C_{p}=1$ diperoleh persamaan sebagai berikut:

$\sigma_{y}^{2} \sum_{i=2}^{N} \sum_{j=1}^{M}\left(\left.\frac{\partial y}{\partial x_{1}}\right|_{\pi \times 1}\right)^{2}\left(\frac{t_{i j}}{3}\right)^{2} \cdot x_{i j}$

Turunan parsial $\left.\frac{\partial y}{\partial x_{1}}\right|_{\pi \times 1}$ pada Persamaan (14), menunjukkan sensitivitas karakteristik kualitas produk akhir (Y) terhadap karakteristik kualitas individu yang dihasilkanpadasetiap tahapan proses ke- $i$ (Xi). Nilai turunan parsial tersebut dapat diperoleh dengan memasukkan nilai nominal target kualitas masing tahapan proses ke- $i$ $\left(t_{x i}\right)$. Hasil turunan parsial ini akan bernilai konstan pada produk yang mempunyai rantai toleransi linier dan tidak konstan pada produk dengan rantai toleransi nonlinier.Jika variansi $\partial \mathrm{y}=\frac{\mathrm{t}_{y}}{3}$ maka toleransi ty $=\partial y .3$, sehingga Persamaan (14) dapat ditulis menjadi Persamaan (15) sebagai berikut:

$$
t_{y}^{2} \sum_{i=2}^{N} \sum_{j=1}^{M}\left(\left.\frac{\partial y}{\partial x_{1}}\right|_{\pi \times 1}\right)^{2}\left(\frac{t_{i j}}{3}\right)^{2} \cdot x_{i j}
$$

Kualitas produk akhir dapat dikatakan memenuhi spesifikasi kualitas pesanan jika nilai toleransi kualitas produk akhir $\mathrm{t}_{\mathrm{y}}$ lebih kecil dari nilai toleransi kualitas produk pesanan $t_{d}$ atau $t_{y} \leq t_{d}$ atau $t_{y}{ }^{2} \leq t_{d}{ }^{2}$. Kondisi ini menjadi fungsi pembatas dalam model optimasi. Pembatas toleransi kualitas dapat dituliskan menjadi persamaan sebagai berikut:

$$
\left.\sum_{i=1}^{I} \sum_{j=1}^{I} \sum_{s=0}^{S} \ldots\left(\frac{\partial y}{\partial x_{1}} \mid \tau_{\mathrm{x} 1}\right)^{2}\left(\frac{\mathrm{t}_{\mathrm{ijs}}}{3}\right)^{2}\right) \cdot x_{i j s}<\left(\mathrm{t}_{\mathrm{d}}\right)^{2}
$$

\section{PEMBAHASAN \\ Parameter Input}

Parameter input yang digunakan pada penelitian ini dipergunakan untuk menjalankan model matematis yang telah dilakukan. Untuk mendapatkan hasil optimal dari model persamaan matematis berupa persamaan algoritma diinputkan ke dalam suatu sistem perangkat lunak (software) Lindo 6.1. Parameter-parameter input yang dipergunakan pada model matematis ini adalah data komponen, data alternatif rancangan dari tiap-tiap komponen, dan data alternatif pemasok termasuk unit produksi sendiri, data biaya pelibatan pemasok untuk pengadaan komponen, data biaya perakitan untuk tiap-tiap tahapan proses perakitan, data spesifikasi toleransi setiap rancangan proses.

Pada penelitian ini, eksekusi model dilakukan dengan studi kasus terhadap produk contoh berupa produk Universal Serial Bus (USB) flashdisk (Rizkianda, 2009). Proses analisis dilakukan dengan mengubah-ubah parameter yang digunakan pada produk tersebut untuk mengetahui sejauhmana perubahan parameter akan mempengaruhi keputusan yang dihasilkan oleh model. Produk ini memiliki 6 buah komponen dan pada tiap-tiap komponen memiliki3 alternatif rancangan. Tiap-tiap komponen memiliki 4 alternatif pemasok/sub-kontraktor termasuk unit produksi sendiri. Produk USB flashdisk ini memiliki 5 tahapan proses perakitan dan karena tiap-tiap rancangan komponen memiliki 3 alternatif rancangan, maka pada

\begin{tabular}{|c|c|c|c|c|c|}
\hline 1 & $j$ & $\begin{array}{c}\text { Nama } \\
\text { Komponen }\end{array}$ & 1 & J & $\begin{array}{c}\text { Nama } \\
\text { Komponen }\end{array}$ \\
\hline \multirow{3}{*}{1} & 1 & USB Jack & \multirow{3}{*}{4} & 1 & Memory 2GB \\
\hline & 2 & dummy & & 2 & Memory 4GB \\
\hline & 3 & dummy & & 3 & Memory 8GB \\
\hline \multirow{3}{*}{2} & 1 & Circuit Board & \multirow{3}{*}{5} & 1 & Casing $A$ \\
\hline & 2 & dummy & & 2 & Casing $B$ \\
\hline & 3 & dummy & & 3 & Casing $C$ \\
\hline \multirow{3}{*}{3} & 1 & Controller & \multirow{3}{*}{6} & 1 & Tutup A \\
\hline & 2 & dummy & & 2 & Tutup B \\
\hline & 3 & dummy & & 3 & Tutup C \\
\hline
\end{tabular}
tiap-tiap tahapan proses perakitan memiliki 9 alternatif proses.

Tabel 1 Komponen USB Flashdisk 
Dari Tabel 1, diketahui bahwa komponen 1, 2, dan 3 hanya memiliki sebuah alternatif rancangan karena menggunakan komponen standar. Guna mempermudah perhitungan ketiga komponen tersebut "dianggap" juga memiliki 3 alternatif rancangan,tetapi ketiga alternatif rancangan "dummy" tersebut akan memiliki parameter biaya yang sama. Sementara itu komponen 4,
5, dan 6 masing-masing memiliki 3 alternatif rancangan sehingga pada ketiga komponen inilah tergantung bentuk rancangan dan spesifikasi produk yang akan dihasilkan. Hubungan keterkaitan antar-komponen dalam produk USB flashdisk digambarkan dengan menggunakan Liaison Graph seperti pada Gambar 1.

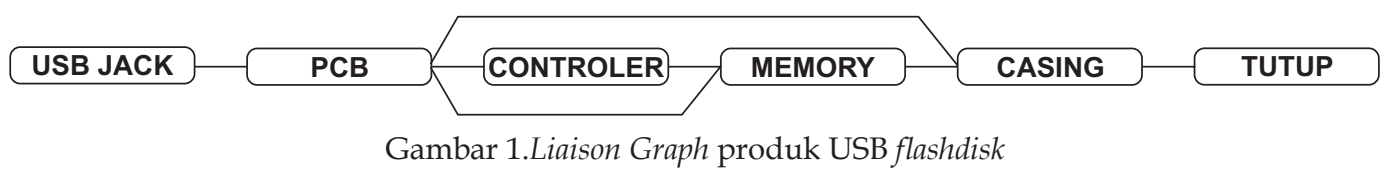

Urutan proses perakitan komponenkomponen pada produk USB flashdisk dibuat berdasarkan hubungan keutamaan antar-komponen. Untuk menggambarkan hubungan keutamaan antar-komponen produk digunakan skema Assembly Precedence Diagram (APD). Skema APD produk USB flashdisk disajikan pada Gambar 2.

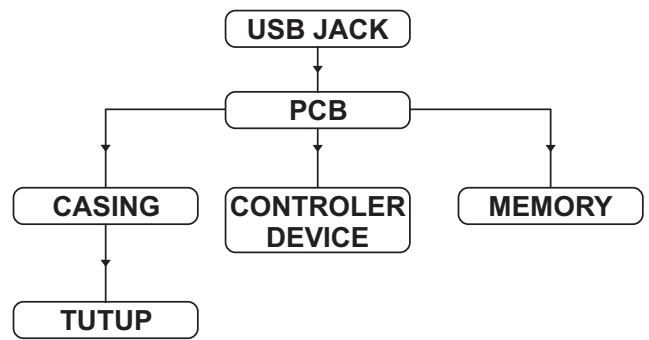

Gambar 2. Skema APD produk USB flashdisk

Berdasarkan skema APD seperti pada Gambar 2, produk USB flasdisk memiliki dua urutan perakitan yang layak. Alternatif 1 adalah (USB Jack-Circuit Board, Circuit Board-Controller Chip, Circuit Board-Memory
Chip, Circuit Board-Casing, Casing-Tutup) dan alternatif 2 adalah (USB Jack-Circuit, Circuit Board-Memory Chip, Circuit Board-Controller Chip, Circuit Board-Casing, Casing-Tutup). Urutan perakitan yang akan digunakan sebagai input pada model ditentukan secara acak berdasarkan alternatif urutan perakitan yang layak. Pada kasus ini urutan perakitan yang digunakan adalah alternatif 1 .

Data yang digunakan pada contoh kasus produk USB flashdisk ini merupakan data hipotetik (Rizkianda, 2009). Data mengenai parameter harga komponen disajikan pada Tabel 2. Tabel 2berisi data parameter harga komponen-komponen yang digunakan pada produk USB flashdisk untuk tiap-tiap rancangan pada masing-masing pemasok atau pabrik manufaktur sub-kontraktor. Data yang digunakan pada setiap komponen adalah $\mathrm{P}_{\mathrm{ijs}}\left(\mathrm{t}_{0}\right)$ yaitu harga komponen pada waktu $t_{0}, P_{\text {ijs }}(t)$ yaitu harga komponen pada waktu t. Sedangkan $\Delta t$ merupakan lama periode waktu antara $\mathrm{t}_{0} \operatorname{sampai} \mathrm{t}\left(\Delta \mathrm{t}=\mathrm{t}-\mathrm{t}_{0}\right)$. 
Tabel 2 harga komponen flashdisk (Rizkianda, 2009)

\begin{tabular}{|c|c|c|c|c|c|c|c|c|c|}
\hline \multirow[b]{2}{*}{ Komponen } & \multirow[b]{2}{*}{ Rancangan } & \multirow[b]{2}{*}{ Pemasok } & \multicolumn{2}{|c|}{ biaya produksi } & biaya & \multirow[b]{2}{*}{ Profit } & \multirow[b]{2}{*}{$\operatorname{Pijs}(\mathrm{t})$} & \multirow[b]{2}{*}{ Pijs(to) } & \multirow[b]{2}{*}{$? \mathrm{t}$} \\
\hline & & & material & proses & Transportasi & & & & \\
\hline \multirow[b]{4}{*}{ USB HEAD } & 1 & 0 & $\mathrm{M}$ & $\mathrm{M}$ & $\mathrm{M}$ & $\mathrm{M}$ & $\mathrm{M}$ & $\mathrm{M}$ & 3 \\
\hline & & 1 & 1442,1 & 4326,1 & 1442,1 & 15481,5 & 24133,6 & 18131,9 & 3 \\
\hline & & 2 & 1399,8 & 4199,3 & 1399,8 & 15027,7 & 23426,2 & 17600,4 & 3 \\
\hline & & 3 & 1433,6 & 4300,7 & 1433,6 & 15390,8 & 23992,1 & 18025,6 & 3 \\
\hline \multirow[b]{4}{*}{ PCB } & 1 & 0 & $\mathrm{M}$ & $\mathrm{M}$ & $\mathrm{M}$ & $\mathrm{M}$ & $\mathrm{M}$ & $\mathrm{M}$ & 3 \\
\hline & & 1 & 1031,5 & 3094,3 & 1031,5 & 16786,9 & 22975,4 & 17261,8 & 3 \\
\hline & & 2 & 1001,2 & 3003,6 & 1001,2 & 16294,9 & 22302 & 16755,8 & 3 \\
\hline & & 3 & 1025,4 & 3076,1 & 1025,4 & 16688,5 & 22840,7 & 17160,6 & 3 \\
\hline \multirow[b]{4}{*}{ Controller } & 1 & 0 & $\mathrm{M}$ & $\mathrm{M}$ & $\mathrm{M}$ & $\mathrm{M}$ & $\mathrm{M}$ & $\mathrm{M}$ & 3 \\
\hline & & 1 & 1541,7 & 4624,9 & 1541,7 & 16633,6 & 25883,3 & 19446,5 & 3 \\
\hline & & 2 & 1496,5 & 4489,3 & 1496,5 & 16146,1 & 25124,6 & 18876,5 & 3 \\
\hline & & 3 & 1532,6 & 4597,8 & 1532,6 & 16536,1 & $25731, \emptyset$ & 19332,5 & 3 \\
\hline \multirow[b]{12}{*}{ Memory } & $2 \mathrm{~GB}$ & 0 & $\mathrm{M}$ & $\mathrm{M}$ & $\mathrm{M}$ & $\mathrm{M}$ & $\mathrm{M}$ & $\mathrm{M}$ & 1 \\
\hline & & 1 & 7145,8 & 21437,3 & 7145,8 & 15465,1 & 58339,5 & 167609 & 1,3 \\
\hline & & 2 & 7145,8 & 21437,3 & 7145,8 & 13755,1 & 56629,5 & 162697 & 1,3 \\
\hline & & 3 & 7145,8 & 21437,3 & 7145,8 & 15123,1 & 57997,5 & $16662 \lambda$ & 1,3 \\
\hline & $4 \mathrm{~GB}$ & 0 & $\mathrm{M}$ & $\mathrm{M}$ & $\mathrm{M}$ & $\mathrm{M}$ & $\mathrm{M}$ & $\mathrm{M}$ & 1 \\
\hline & & 1 & 7145,8 & 21437,3 & 7145,8 & 65870,4 & 108745 & 194001 & 1 \\
\hline & & 2 & 7145,8 & 21437,3 & 7145,8 & 62682,9 & 105557 & 188314 & 1 \\
\hline & & 3 & 7145,8 & 21437,3 & 7145,8 & 65232,9 & 108107 & 192863 & 1 \\
\hline & $8 \mathrm{~GB}$ & 0 & $\mathrm{M}$ & $\mathrm{M}$ & $\mathrm{M}$ & $\mathrm{M}$ & $\mathrm{M}$ & $\mathrm{M}$ & 1 \\
\hline & & 1 & 7145,8 & 21437,3 & 7145,8 & 124963 & 167837 & 227755 & 0,8 \\
\hline & & 2 & 7145,8 & 21437,3 & 7145,8 & 120043 & 162917 & 221079 & 0,8 \\
\hline & & 3 & 7145,8 & 21437,3 & 7145,8 & 123979 & 166853 & $22642 \phi$ & 0,8 \\
\hline \multirow[b]{12}{*}{ Casing } & $\mathrm{A}$ & 0 & 89,7 & 269 & 89,7 & 966,4 & 1504,41 & 1304 & 1,5 \\
\hline & & 1 & 75,4 & 226,1 & 75,4 & 812,3 & 1264,44 & 1096 & 1,5 \\
\hline & & 2 & 95,4 & 286 & 95,4 & 1027,2 & 1599,01 & 1386 & 1,5 \\
\hline & & 3 & 79,1 & 237,3 & 79,1 & 852,3 & 1326,74 & 1450 & 1,5 \\
\hline & $B$ & 0 & 83 & 249 & 83 & 894,6 & 1392,5 & 1207 & 1,5 \\
\hline & & 1 & 76,2 & 228,4 & 76,2 & 820,4 & 1277,13 & 1107 & 1,5 \\
\hline & & 2 & 89 & 266,8 & 89 & 958,2 & 1491,72 & 1293 & 1,5 \\
\hline & & 3 & 89,8 & 269,2 & 89,8 & 967,2 & 1505,57 & 1305 & 1,5 \\
\hline & $\mathrm{C}$ & 0 & 85,2 & 255,4 & 85,2 & 917,5 & 1428,27 & 1238 & 1,5 \\
\hline & & 1 & 99,8 & 299,4 & 99,8 & 1075,4 & 1674 & 1451 & 1,5 \\
\hline & & 2 & 102,3 & 306,8 & 102,3 & 1102,1 & 1715,54 & 1487 & 1,5 \\
\hline & & 3 & 93,8 & 281,4 & 93,8 & 1010,1 & 1573,63 & 1364 & 1,5 \\
\hline \multirow{13}{*}{ Cap } & A & 0 & 78,9 & 236,7 & 78,9 & 850,1 & 1323,28 & 1147 & 1,5 \\
\hline & & 1 & 83,7 & 251,1 & 83,7 & 902 & 1404,04 & 1217 & 1,5 \\
\hline & & 2 & 94 & 282 & 94 & 1013,2 & 1577,09 & 1367 & 1,5 \\
\hline & & 3 & 80,5 & 241,4 & 80,5 & 867,1 & 1349,82 & 1170 & 1,5 \\
\hline & $\mathrm{B}$ & 0 & 91,2 & 273,4 & 91,2 & 982 & 1528,64 & 1325 & 1,5 \\
\hline & & 1 & 94,1 & 282,2 & 94,1 & 1013,9 & 1578,25 & 1368 & 1,5 \\
\hline & & 2 & 99,1 & 297,3 & 99,1 & 1068 & 1662,47 & 1441 & 1,5 \\
\hline & & 3 & 80,2 & 240,4 & 80,2 & 863,4 & 1344,05 & 1165 & 1,5 \\
\hline & C & 0 & 80,8 & 242,4 & 80,8 & 870,9 & 1355,59 & 1175 & 1,5 \\
\hline & & 1 & 96,5 & 289,5 & 96,5 & 1039,8 & 1618,63 & 1403 & 1,5 \\
\hline & & 2 & 91,4 & 274,2 & 91,4 & 985 & 1533,25 & 1329 & 1,5 \\
\hline & & 3 & 79,5 & 238,5 & 79,5 & 856,8 & 1333,61 & 1156 & 1,5 \\
\hline & & & & & & & sumber: & vww.king & $\mathrm{com}$ \\
\hline
\end{tabular}


Parameter biaya yang lain yang digunakan adalah biaya pelibatan pemasok/ pabrik manufaktur sub-kontraktor untuk pengadaan komponen (Fine, at.al 2005). Biaya pelibatan pemasok/pabrik manufaktur subkontraktor adalah biaya yang dikeluarkan untuk melibatkan pemasok/pabrik manufaktur sub kontraktor s ke dalam sistem manufaktur. Model pada penelitian ini biaya pelibatan pemasok/pabrik manufaktur subkontraktor dibedakan berdasarkan komponen sehingga dinotasikan sebagai Pis. Data hipotetik mengenai biaya tersebut disajikan pada Tabel 3.

Tabel 3 Biaya Pelibatan Pemasok Komponen USB (flashdisk) (Rizkianda, 2009)

\begin{tabular}{c|l|l}
\hline Komponen & Pemasok & Pis (Rp) \\
\hline \multirow{4}{*}{ USB Head } & 0 & 11729 \\
\cline { 2 - 3 } & 1 & 11143 \\
\cline { 2 - 3 } & 2 & 10682 \\
\cline { 2 - 3 } & 3 & 13167 \\
\hline \multirow{4}{*}{ PCB } & 0 & 11609 \\
\cline { 2 - 3 } & 1 & 12491 \\
\cline { 2 - 3 } & 2 & 13859 \\
\cline { 2 - 3 } & 3 & 13752 \\
\hline \multirow{5}{*}{ Controller } & 0 & 14401 \\
\cline { 2 - 3 } & 1 & 13099 \\
\cline { 2 - 3 } & 2 & 10577 \\
\cline { 2 - 3 } & 3 &
\end{tabular}

Parameter biaya lain yang digunakan dalam perhitungan adalah biaya perakitan komponen. Data mengenai biaya perakitan untuk tiap-tiap tahapan proses perakitan disajikan pada Tabel 4. Asumsi yang digunakan untuk membangkitkan data hipotetik yang disajikan pada Tabel 4 antara

\begin{tabular}{l|l|l}
\hline Komponen & Pemasok & Pis (Rp) \\
\hline \multirow{4}{*}{ Memory } & 0 & 12722 \\
\cline { 2 - 3 } & 1 & 14125 \\
\cline { 2 - 3 } & 2 & 12499 \\
\cline { 2 - 3 } Casing & 3 & 12910 \\
\hline \multirow{5}{*}{ Cap } & 0 & 12710 \\
\cline { 2 - 3 } & 1 & 12904 \\
\cline { 2 - 3 } & 2 & 13292 \\
\cline { 2 - 3 } & 3 & 11868 \\
\cline { 2 - 3 } & 0 & 13096 \\
\cline { 2 - 3 } & 1 & 11199 \\
\cline { 2 - 3 } & 2 & 12581 \\
\hline
\end{tabular}

lain: Pertama, Biaya perakitan komponen merupakan perkalian dari biaya persatuan waktu yang ditanggung perusahaan untuk merakit komponen dengan lama waktu merakitnya. Kedua, Biaya perakitan persatuan waktu yang digunakan adalah Rp 43,73/ detik (Rizkianda, 2009).

Tabel 4. Biaya perakitan komponen USB flashdisk (Rizkianda, 2009)

\begin{tabular}{l|l|l|l|l|l|l|l|l}
\hline Prju & Ket & Biaya (Rp) & Prju & Ket & Biaya (Rp) & Prju & Ket & Biaya (Rp) \\
\hline P11 & P11-21 & 209.9 & P231 & P23-31 & 167.9 & P421 & P22-51 & 209.9 \\
\hline P112 & P11-22 & 251.9 & P232 & P23-32 & 251.9 & P422 & P22-52 & 251.9 \\
\hline P113 & P11-23 & 167.9 & P233 & P23-33 & 167.9 & P423 & P22-53 & 251.9 \\
\hline P121 & P12-21 & 293.9 & P311 & P21-41 & 167.9 & P431 & P23-51 & 167.9 \\
\hline P122 & P12-22 & 251.9 & P312 & P21-42 & 209.9 & P432 & P23-52 & 167.9 \\
\hline P123 & P12-23 & 335.8 & P313 & P21-43 & 209.9 & P433 & P23-53 & 335.8 \\
\hline P131 & P13-21 & 251.9 & P321 & P22-41 & 251.9 & P511 & P51-61 & 209.9 \\
\hline P132 & P13-22 & 209.9 & P322 & P22-42 & 335.8 & P512 & P51-62 & 167.9 \\
\hline P133 & P13-23 & 209.9 & P323 & P22-43 & 209.9 & P513 & P51-63 & 167.9 \\
\hline P211 & P21-31 & 167.9 & P331 & P23-41 & 167.9 & P521 & P52-61 & 209.9 \\
\hline P212 & P21-32 & 209.9 & P332 & P23-42 & 251.9 & P522 & P52-62 & 209.9 \\
\hline P213 & P21-33 & 209.9 & P333 & P23-43 & 167.9 & P523 & P52-63 & 167.9 \\
\hline P221 & P22-31 & 251.9 & P411 & P21-51 & 251.9 & P531 & P53-61 & 167.9 \\
\hline P222 & P22-32 & 335.8 & P412 & P21-52 & 293.9 & P532 & P53-62 & 335.8 \\
\hline P223 & P22-33 & 209.9 & P413 & P21-53 & 293.9 & P533 & P53-63 & 251.9 \\
\hline
\end{tabular}


Tabel 4 berisi data mengenai biaya tiap-tiap tahapan operasi perakitan dengan masing-masing alternatifnya. Indeks $r$ menyatakan nomor urut proses perakitan, indeks $j$ menyatakan rancangan komponen pendahulu yang akan dirakit dan indeks $u$ menyatakan alternatif proses perakitan yang tersedia. Alternatif proses merupakan pilihan rancangan komponen yang akan dipasangkandirakit dengan komponen pendahulu dalam urutan proses $r$. Setelah semua komponen biaya lengkap maka tahapan berikutnya adalah proses eksekusi model pemilihan rancangan komponen yang menghasikan kombinasi dengan biaya minimum. Model matematika yang dibuat pada penelitian ini dirancang untuk menentukan sebuah rancangan produk melalui pemilihan komponen berdasarkan biaya manufaktur/pembelian, biaya pelibatan pemasok/pabrik manufaktur sub-kontraktor, biaya perakitan dan biaya kualitasnya.

\section{Hasil Komputasi}

Dalam pengolahan parameter input ini,maka parameter-parameter input yang telahdibuat akan dimasukkan dalam persamaan matematis yang dijalankan menggunakan software Lindo 6.1. Pada pengolahan selanjutnya, dibuat suatu skenario eksperimen dari parameter inputagar model matematis ini menghasilkan nilai optimum dari setiap kali dijalankan dan bagaimana kecenderungan nilai hasil yang didapat sesuai dengan tujuan penelitian untuk meminimalkan biaya yang terjadi, sehingga dapat lebih jelas dan membantu pada proses analisa selanjutnya.

Proses analisis yang akan dilakukan terhadap model bertujuan mengetahui dampak yang terjadi terhadap solusi yang dihasilkan model akibat adanya perubahan input parameter yang diberikan kedalam model. Untuk kasus USB flashdisk, proses analisis dilakukan dengan mengubah-ubah input rencana masa produksi (planning horizon). Untuk kepentingan analisis, model akan dieksekusi dengan menggunakan rencana masa produksi 2 tahun sampai dengan 3 tahun dengan pengaruh nilai koefisien biaya kerugian kualitas Ap dibuat tetap $=50$, dari perubahan input tersebut akan diketahui apakah solusi yang akan dihasilkan oleh model ini akan berubah atau tidak.Untuk masa produksi 2 tahun, hasil eksekusi model komputasi disajikan pada Tabel 5.

Tabel 5 Solusi Model $(\mathrm{T} p=2$ thn $)$

\begin{tabular}{l|l|l|l|l|l}
\hline $\begin{array}{c}\text { Kombinasi } \\
\text { Komponen }\end{array}$ & BIAYA (Rp) & $\begin{array}{c}\text { Kombinasi } \\
\text { Pemasok }\end{array}$ & BIAYA (Rp) & $\begin{array}{c}\text { Urutan } \\
\text { Perakitan }\end{array}$ & BIAYA (Rp) \\
\hline X112 & 23426.20 & Y12 & 10682 & A113 & 167.92 \\
\hline X231 & 22975.41 & Y21 & 12491 & A231 & 167.92 \\
\hline X313 & 25731.56 & Y33 & 10577 & A332 & 251.88 \\
\hline X422 & 149726.79 & Y42 & 12499 & A431 & 167.92 \\
\hline X513 & 1326.74 & Y53 & 11868 & A513 & 167.92 \\
\hline X632 & 1533.25 & Y62 & 11199 & & \\
\hline
\end{tabular}

Dengan menggunakan rencana masa produksi Tp $=2$ tahun, dari Tabel 5 solusi yang dihasilkan model adalah berupa kombinasi rancangan komponen K11-K23K31-K42-K51-K63. Komponen K11 (USB jack rancangan 1) dibeli dari pemasok 2 . Komponen K23 (circuit board rancangan 3) dibeli dari pemasok 1. Komponen K31 (controller chip rancangan 1) dibeli dari pemasok3. Komponen K42 (memory chip 4Gb) dibeli dari pemasok 2. Komponen K51 (casing A) dibeli dari pemasok 3 dan komponen K63 (tutup C) dibeli dari pemasok 2. Kombinasi komponen rancangan produk USB flashdisk ini, hanya dapat diproduksi selama 1,41 tahun (1 tahun 4.92 bulan) karena pasokan komponen memory $4 \mathrm{~Gb}$ dari pemasok 2 akan berhenti setelah jangka waktu tersebut. Namun demikian, kombinasi ini merupakan yang paling murah, menghasilkan biaya 
minimum sebesar Rp442.438,53 untuk rencana masa produksi $\mathrm{Tp}=2$ tahun.
Sedangkan untuk masa produksi 2,5 tahun, hasil eksekusi model disajikan pada Tabel 6.

Tabel 6 Solusi Model $(\mathrm{Tp}=2,5 \mathrm{thn})$

\begin{tabular}{l|l|l|l|l|l}
\hline $\begin{array}{l}\text { Kombinasi } \\
\text { Komponen }\end{array}$ & BIAYA (Rp) & $\begin{array}{l}\text { Kombinasi } \\
\text { Pemasok }\end{array}$ & BIAYA (Rp) & $\begin{array}{l}\text { Urutan } \\
\text { Perakitan }\end{array}$ & BIAYA (Rp) \\
\hline X112 & 23426.20 & Y12 & 10682 & A113 & 167.92 \\
\hline X231 & 22975.41 & Y21 & 12491 & A231 & 167.92 \\
\hline X313 & 25731.56 & Y33 & 10577 & A333 & 167.92 \\
\hline X432 & 162917.41 & Y42 & 12499 & A431 & 167.92 \\
\hline X513 & 1326.74 & Y53 & 11868 & A513 & 167.92 \\
\hline X632 & 1533.25 & Y62 & 11199 & & \\
\hline
\end{tabular}

Berdasarkan hasil perhitungan model, maka diperoleh rancangan produk USB flashdisk dengan menggunakan kombinasi rancangan komponen K11-K23-K31-K43K51-K63. Komponen K11 (USB jack rancangan 1) dibeli dari pemasok2. Komponen K23 (circuit board rancangan 3) dibeli dari pemasok 1. Komponen K31 (controller chip rancangan 1) dibeli dari pemasok 3 . Komponen K43 (memory chip $8 \mathrm{~Gb}$ ) dibeli dari pemasok 2. Komponen K51 (casing A) dibeli dari pemasok 3 dan komponen K63 (tutup C) dibeli dari pemasok 2. Kombinasi ini menghasilkan biaya minimum sebesar Rp 455.545,18. Berdasarkan hasil perhitungan, rancangan USB flashdisk yang dihasilkan dari eksekusi model hanya dapat diproduksi untuk jangka waktu maksimal 2,65 tahun (2 tahun 7.8 bulan) karena komponen K43 hanya akan diproduksi oleh pemasok/pabrik manufaktur 2 untuk 2 tahun 7,8 bulan.

Berdasarkan hasil pengujian, model ini dapat bekerja sebagaimana mestinya. Model ini mampu memilih rancangan komponen sehingga menghasilkan sebuah produk dengan kombinasi rancangan komponen yang memiliki biaya rendah. Ringkasan kombinasi rancangan komponen hasil dari eksekusi model untuk masing-masing nilai Tp disajikan pada Tabel 7.

Tabel 7 Solusi Model untuk Tp=2.5, Tp=3

\begin{tabular}{l|l|l|l|l}
\hline \multirow{1}{*}{ Tp } & \multicolumn{2}{c|}{ KOMBINASI } & \multicolumn{1}{c}{ Biaya } & \multicolumn{1}{c}{$\begin{array}{c}\text { Waktu produksi maksimal/ } \\
\text { kontinuitas }\end{array}$} \\
\hline$(\mathrm{TAHUN})$ & komponen & pemasok & Total & (tahun) \\
\hline 2 & K11-K23-K31 & Y12-Y21-Y23- & $442.438,53$ & 1.41 \\
\hline 2.5 & K42-K51-K63 & Y42-Y53-Y62 & & \\
\hline & K11-K23-K31 & Y12-Y21-Y33- & $455.545,18$ & 2.65 \\
\hline 3 & K43-K51-K63 & Y42-Y53-Y62 & & \\
\hline & K11-K23-K31 & Y12-Y21-Y33- & $477.062,58$ & 2.65 \\
\hline
\end{tabular}

Berdasarkan hasil pengujian yang disajikan pada Tabel7, diketahuibahwa solusi model mengalami perubahan ketika nilai Tp diturunkan dari 2,5 tahun menjadi 2 tahun. Akan tetapi, ketika Tp dinaikan menjadi 3 tahun, solusi yang dihasilkan model tidak mengalami perubahan. Walaupun solusi model tidak berubah, biaya total pada $\mathrm{Tp}=3$ tahun lebih besar daripada ketika model $\mathrm{Tp}=$
2,5 tahun. Hal ini terjadi karena bobot akibat kontinuitas pasokan yang ditanggung pada $\mathrm{Tp}=3$ tahun lebih besar. Bila menentukan solusi, model ini sudah mempertimbangkan aspek yang berkaitan dengan kontinuitas pasokan komponen, dan juga pengaruh laju inflasi terhadap perubahan hargaharga barang. Berdasarkan hasil uji dengan menggunakan kasus produk USB flashdisk 
(Rizkianda, 2009), model ini terbukti mampu bekerja dengan baik untuk produkproduk yang mengalami penurunan akibat perkembangan teknologi. Hal ini terlihat dari komponen-komponen yang terdapat dalam produk USB flashdisk ada yang mengalami proses penurunan nilai akibat keusangan teknologi dan ada yang tidak. Pada produk USB flashdisk contoh komponen yang paling jelas mengalami keusangan teknologi adalah komponen memory chip. Komponen ini sekaligus menjadi alat ukur yang tepat untuk menentukan rencana masa produksi karena umur komponen relatif pendek dibanding dengan komponen yang lain.

\section{SIMPULAN}

Simpulan yang diperoleh dari penelitanini sebagai berikut:Pertama,Model dapat bekerja untuk memilih komponen dengan kriteria performansi biaya manufaktur/pembelian, biaya pelibatan pemasok/subkontraktor, biaya perakitan dan biaya kerugian kualitas. Solusi yang dihasilkan model adalah berupa sebuah rancangan produk dengan kombinasi rancangan komponen dan kombinasi pemasok/ subkontraktor yang memberikan biaya total terendah. Kedua, Hasil uji coba pada produk USB flashdisk menunjukkan bahwa model dapat diterapkan baik pada produk yang mengalami penurunan nilai akibat keusangan teknologi. Ketiga, Perubahan nilai koefisien kerugian kualitas (Ap) tidak mempengaruhi skenario rancangan proses.

Selanjutnya berdasarkan apa yang telah dilakukan, maka saran yang dapat diberikan pada penelitian ini sebagai berikut: pertama, Model ini belum mampu mengakomodasikan laju inflasi yang berubah-ubah sehingga perlu ada penelitian yang mampu mengakomodasikan hal tersebut. Kedua, Alternatif proses yang tersedia tidak hanya dalam satu pemasok, tetapi terdapat pada beberapa pemasok dalam sebuah jaringan manufaktur, dengan demikian perlu memperhitungkan ongkos transportasi.
Ketiga, Apabila nilai karakteristik kualitas dari hasil setiap alternatif proses tidak sama dengan nilai target, maka perlu diperhitungkan untuk toleransi yang bersifat asimetris.

\section{DAFTAR PUSTAKA}

Boothroyd, G., Dewhust, P., Knight, W.A., 1994. Product Design for Manufacturing and Assembly. M. Dekker. New York.

Bopana, K.G., Chon-Huat, G., 1997. A Hierarchical System of Performance Measure for Concurrent Engineering. Concurrent Engineering: Research and Application 5(2): 137-143.

Campanella, J. (1990) Principles of quality costs, $2^{\text {nd }}$ Edition, Quality Press, Milwaukee.

Feng, C., Wang, J., Wang, J.S., 2001. An Optimization Model of Concurrent Selection of Tolerances and Suppliers. Computers and Industrial Engineering 40:15-33.

Fine, C.H., Golany, B., Naseraldin, H., 2005. Modelling Tradeoffs in Three-Dimensional Concurrent Engineering: A Goal Programming Approach. Journal of Operation Management (23): 389-403.

Gunasekaran, G., 1998. Concurrent Engineering: A Competitive Strategy for Process Industries. Journal of Operational Research Society 49: 758765.

Irianto, D. and Rahmat, D. (2008) A Model for Optimizing Process Selection for MTO Manufacturer with Appraisal Cost,Proceedings $9^{\text {th }} \quad$ Asia Pacific Industrial Engineering \& Management Systems (APIEMS) Conference, 220225.

Marian, R.M., 2003. Optimisation of Assembly Sequences Using Genetic Algorithms. Doctoral Dissertation. School of Advance Manufacturing and 
BUDI SUSANTO, MK HERLIANSYAH, ALVA EDY TONTOWI MODEL INTEGRASI DESIGN DAN PROSES MANUFAKTUR PADA PERAKITAN PRODUK MULTI PEMASOK

Mechanical Engineering. University of South Australia.

Montgomery, D.C. (2001) Introduction to Statistical Quality Control, $4^{\text {th }} \mathrm{Ed}$. John Willey \& Sons, Inc., Singapore.

Rizkianda, A.B, 2009. Model Pemilihan Komponen Pada Rancangan Produk
Pada Tahap Perancangan Fisik Produk. Tesis. Teknik dan Manajemen Industri, Institut Teknologi Bandung. Taguchi, G. (1988) Quality Engineering in Product Development - Design Level. Japan Standard Association, Tokyo. 